\title{
Benlik Saygısı ve Organ Bağışı Tutumu İlişkisi: Üniversite Öğrencileri Üzerine Bir Araştırma
}

HARUN KIRILMAZ*

hkirilmaz@sakarya.edu.tr

ORCID ID: 0000-0001-6055-6826

\author{
PELINSU BUKET GÜLER** \\ p.buket.guler@gmail.com \\ ORCID ID: 0000-0002-5108-473X
}

Öz: Bu çalışmanın amacı, üniversite öğrencilerinin benlik saygısı düzeyleri ve organ bağışı tutumları ilişkisini incelemektir. Araştırma örneklemini Sakarya Üniversitesi İşletme Fakültesinde okuyan 250 öğrenci oluşturmuştur. Veri toplama aracı olarak "Organ Bağışı Tutum Ölçeği”, "Benlik Saygısı Ölçeğì" ve öğrencilere ait kişisel bilgi formu kullanılmıştır. Araştırma bulgularına göre organ bağışı ile ilgili bilgilerin en fazla görsel medya aracılı̆̆ıla elde edildiğ i görülmüştür. Üniversite öğrencilerin benlik saygısı orta düzeydedir. Benlik saygısı ile organ bağışı tutumu arasında pozitif yönde ve istatistiksel açıdan anlamlı ilişki bulunmuştur. Benlik saygısı, organ bağışı tutumunu olumlu yönde etkilemektedir. Üniversite öğrencilerin benlik saygısı düzeyleri artıkça organ bağışı tutum düzeylerinin de artacağı düşünülmektedir. Ayrıca organ bağışı tutum ölçeğinin alt boyutu olan altruistik değer ile cinsiyet, yaş ve sinıf arasında anlamlı bir farklılık bulunmuştur. Organ bağışı ile ilgili eğitimlerin yapılması, öneminin anlatılması, gençlerin bağış kampanyalarına katılması gibi faaliyetler öğrencilerin ve toplumun organ bağışı konusunda bilinçlenmesine ve farkındalıklarının artmasına yararlı olacaktır.

Anahtar kelimeler: Benlik saygısı, Organ nakli, Organ bağışı.

\section{Giriş̧}

Bireyin mutlu ve kaliteli bir şekilde yaşamını sürdürebilmesinde sağlıklı bir kişilik gelişimine sahip olması gerekmektedir. Bireyin kendisini olumlu ya da olumsuz kabul etmesi, hayatının anlamlı olup olamadığı gibi değerlendirmelerini içeren benlik saygısı kavramı önem kazanmaktadır. Yüksek benlik saygısına sahip olan bireyler, önemli yaşam görevlerinde başarılı olma ve toplumda daha aktif görevlere katılma gibi faydalı faaliyetleri gerçekleştirmektedirler. Benlik saygısı kişinin kendini yetenekli, anlamlı, başarılı ve layık olarak görmeye inancını ifade etmektedir. Yüksek benlik saygısının olumlu kişilik özelliklerinin ortaya çıkışında, motivasyonun sağlanmasında, stresle baş etmede katkıda bulunduğu kabul edilmektedir. Diğer taraf-

\footnotetext{
* Doç. Dr., Sakarya Üniversitesi, İşletme Fakültesi, Sağlık Yönetimi Bölümü.

** Yüksek Lisans Öğrencisi, Sakarya Üniversitesi, İşletme Enstitüsü, Sağlık Yönetimi Programı.
} 
tan yüksek benlik saygısına sahip kişilerin iş hayatında sorumluluk üstlenme ve toplumda aktif görev alma gibi olumlu özelliklerinin de ön plana çıtığı görülmektedir. Yüksek benlik saygısının pozitif yönlerinden biri de toplumsal faydalara açık kişilik özellerinin ön plana çıkarak organ bağışında bulunma istek ve tutumuna katkı sağlaması olduğunu söylemek mümkündür. Bu çalışmadan elde edilecek bulgular ile benlik saygısı ile organ bağışı tutumu arasındaki ilişkiye dikkat çekilmesi ve toplumda organ bağışında bulunma isteği ve tutumuna katkı sağlaması ümit edilmektedir.

\section{Kavramsal Çerçeve}

Toplumu oluşturan insanların davranışlarına, tutum ve inançlarına, düşüncelerine yön verebilen benlik saygısı, bireyin kendini değerlendirmesi sonucu ulaştığı, benlik kavramının onaylamasından doğan olumlu veya olumsuz tutumu olarak tanımlanmaktadır. ${ }^{1}$ Bireyin nelerin üstesinden gelebileceği, neleri başarabileceği, nelere ne düzeyde önem verdiği gibi özelliklerini ortaya koymaktadır. ${ }^{2}$ İnsan motivasyonu için vazgeçilmez bir güç olarak görülmekte aynı zamanda olumlu değişkenlerle ilişkilendirilir. ${ }^{3}$ Bireyin özerkliğini kazanması, yaşamdan doyum alması, amaca yönelik etkinlikte bulunması, yaptıklarının sorumluluğunu kabullenmesi, değer sistemlerini geliştirmesi, başarılı olması, geleceği doğru planlayabilmesi bu tür değişkenlere örnek gösterilebilir. ${ }^{4}$ Hem diğer kişilerden etkilenen hem de diğer kişileri etkileyen, sonucunda fiziksel ve ruhsal boyutlarda pek çok etkilere neden olan ve çeşitli davranışlara da yön verebilen önemli bir yapıdır. ${ }^{5} \mathrm{Bu}$ nedenle yeniliklere açık, iletişim becerileri gelişmiş, yaratıcı ve araştırmacı niteliklerinden dolayı birey toplumda daha aktif görevler almaktadır. ${ }^{6}$ Eğer kişi kendini olumlu bir şekilde değerlendiriyorsa, benlik saygısı yüksek, olumsuz olarak değerlendirmesi ise, benlik saygısının düşük olduğu ifade edilmektedir. ${ }^{7}$

Yüksek benlik saygısına sahip olan bireylerin kendine güvenen, başarma isteği yüksek, iyimser, zorluklardan yılmayan, kendilerini saygıdeğer, önemli ve yararlı görme eğiliminde olan ve çevreye karşı duyarlı faaliyetlerde bulunma gibi özelliklere sahiptir. Ayrıca diğer insanlarla sağlıklı ve sürekli iletişim kuran, girişimci ve yaratı-

\footnotetext{
1 Nülüfer Erbil ve Özgül Bostan, “Ebe ve Hemşirelerde İş Doyumu, Benlik Saygısı ve Etkileyen Faktörler”, Atatürk Üniversitesi Hemşirelik Yüksekokulu Dergisi, 7/3 (2004), s.57.

2 Gülendam Karadağ vd., "Gaziantep Üniversitesi Sağlık Yüksekokulu Hemşirelik Öğrencilerinin Benlik Saygıları”, Fırat Sağlık Hizmetleri Dergisi, $3 / 7$ (2008), s.31.

3 Özlem Karaırmak ve Rahşan Siviş-Çetinkaya, “Benlik Saygısının ve Denetim Odağının Psikolojik Sağlamlık Üzerine Etkisi: Duyguların Aracı Rolü”, Türk Psikolojik Danışma ve Rehberlik Dergisi, 4/35 (2011), s.31.

4 E. Erdal Erşan, Orhan Doğan ve Selma Doğan, "Beden Eğitimi ve Antrenörlük Bölümü Öğrencilerinde Benlik Saygısı Düzeyi ve Bazı Sosyo-Demografik Özelliklerle İlişkisi”, Klinik Psikiyatri, 12/1 (2009), s.36.

5 O. Tolga Arıcak, "Üniversite Öğrencilerinde Benlik Saygısı”, Psikoloji Çalışmaları, 25 (2005), s.20. Hatice Altıok Öner, Nurcan Ek ve Nermin Koruklu, “Üniversite Öğrencilerinin Benlik Saygı Düzeyi ile İlişkili Bazı Değişkenlerin İncelenmesi”, Adnan Menderes Üniversitesi Eğitim Fakültesi Eğitim Bilimleri Dergisi, 1/1 (2010), s.101-102.

6 Muhammet Sıddık Taşgit, "Üniversite Öğrencilerinin Benlik Saygısı ve Karar Verme Düzeylerinin İncelenmesi”, Yüksek Lisans Tezi, Karamanoğlu Mehmet Bey Üniversitesi, 2012, s.16.

7 Derya Tanrıverdi vd., "Lise Öğrencilerinin Yeme Tutumları, Yeme Davranışları ve Benlik Saygılarının İncelenmesi”, Gaziantep Tip Dergisi, 17/1 (2011), s.33.
} 
cılardır. ${ }^{8}$ Düşük benlik saygısına sahip kişiler ise canlılık ve enerjilerini kaybetmiş, kendilerine güvenmeyen, hatta kendini utanç verici değersiz ve çaresiz hisseden, başarı ve becerileri azalmış kişilerdir. ${ }^{9}$

Son dönemde sağlık hizmetlerinde en hızlı ilerleyen alanlardan biri olan doku ve organ nakli, geri dönüşü olmayan yaşamsal organ yetmezliklerine karşı uygulanan geçerli, başarılı ve ileri düzeyde bir tedavi yöntemi olarak kabul edilmektedir. ${ }^{10} \mathrm{Bu}$ sayede organ yetmezliği nedeniyle yaşamının sonuna gelmiş bir hastanın hayatı kurtulmakta, yaşam kalitesi artmakta ve yaşam süresi uzamaktadır. ${ }^{11}$ Organ nakli, vücutta görevini yapamayan bir organın yerine canlı bir vericiden veya kadavradan alınarak sağlam bir doku veya organa nakledilmesi işlemidir. ${ }^{12}$ Organ nakillerinin yapılabilmesi, nakledilecek organların temini organ bağışı ile mümkün olmaktadır. ${ }^{13}$ Organ bağışı ise, kişinin hayatta iken serbest iradesi ile tıbben yaşamı sona erdikten sonra doku ve organlarının başka hastaların tedavisi için kullanılmasına izin vermesi ve bunu belgelendirmesidir. ${ }^{14}$

Organ bağışı yapabilmek için bireyin 18 yaşını doldurmuş, akli dengesi yerinde ve en az iki tanık huzurunda sözlü veya yazılı olarak açıklaması imzaladığı tutanağın bir hekim tarafından onaylanması ve bunun için en yakın sağlık kuruluşuna başvurarak "Doku ve Organ Bağışı Belgesi” alması gerekmektedir. ${ }^{15}$ Türkiye'de ilk başarılı organ nakli 1975 yılında ve ilk kadavra böbrek nakli ise 1979'da Prof. Dr. Mehmet Haberal ve ekibi tarafından ve gerçekleştirilmiştir. ${ }^{16}$ Türkiye'de organ bağışı ve nakli 3 Haziran 1979 tarih ve 2238 sayılı yasaya göre "Organ ve Doku Alınması, Saklanması, Aşılanması ve Nakli Hakkındaki Kanun” çerçevesinde uygulamalar yapılmaktadır. ${ }^{17}$ $\mathrm{Bu}$ yasaya göre organ bağışı ya kişinin hayatta iken organ bağışı yaptığını organ bağ kartı edinerek yasallaştırması ya da hastanın yakınlarının tıbben ölümün tespitinden

8 Neslihan Sam, Rıza Sam ve K. Burcu Öngen, "Üniversite Öğrencilerinin Çevresel Tutumlarının Yeni Çevresel Paradigma ve Benlik Saygısı Ölçeği İle İncelenmesi”, Akademik Bakış Açısı, 21 (2010), s.5.

9 İshak Özkan, "Benlik Saygısını Etkileyen Etkenler”, Düşünen Adam, 7/3 (1994), s.5.

10 Elif Yeter ve Savaş Demirtaş, “Organ Nakilleri ve Organ Bağışının Önemi”, erişim 25 Ekim, 2018, http://kisi. deu.edu.tr/bulent.cavas/ders/bok3.pdf, s.2.

11 Funda Özpulat, "Üniversite Öğrencilerinin Kan ve Organ Bağışına İlişkin Düşünceleri”, Sağlık Bilimleri ve Meslekleri Dergisi, 4/2 (2017), s.72.

12 Nurten Özdağ, “Organ Nakli ve Bağıșına Toplumun Bakışı”, Cumhuriyet Üniversitesi Hemşirelik Yüksekokulu Dergisi, 5/2 (2001), s.46.

13 Mehtap Kavurmac1, Neziha Karabulut ve Ayşegül Koç, "Üniversite Öğrencilerinin Organ Bağışı Hakkındaki Bilgi ve Görüşleri”, Hemşirelikte Eğitim ve Araştırma Dergisi, 11/2 (2014), s.16.

14 Mehtap Akış vd., "Süleyman Demirel Üniversitesi Personelinin Organ-Doku Bağışı ve Nakli Hakkındaki Bilgi ve Tutumları”, Süleyman Demirel Üniversitesi Tip Fakültesi Dergisi, 15/4 (2008), s.29.

15 Nurgül Bölükbaş, Ayşe Eyüpoğlu ve Pınar Kurt, "Organ Bağıșı Hakkında Üniversite Öğrencilerinin Düşünceleri”, Ondokuz Mayıs Üniversitesi Tip Dergisi, 21/2 (2004), s.74. Nadiye Özer, Serdar Sarıtaş ve Zeynep Karaman Özlü, "Hemşirelik Öğrencilerinin Organ Nakli ve Bağışı Konusundaki Bilgi ve Düşüncelerinin İncelenmesi”, Anadolu Hemşirelik ve Sağlık Bilimleri Dergisi, 13/2 (2010), s.2.

16 Aytaç Koçak vd., "Ege Üniversitesi Tıp Fakültesi Öğrencilerinin Organ Nakli ve Bağışı Hakkındaki Bilgi Düzeyi”, Ege Tip Dergisi, 49/3 (2010), s.154.

17 Sultan Özkan ve Emel Yılmaz, "Hasta Yakınlarının Organ Bağışı ile İlgili Bilgi ve Tutumları", Aile ve Toplum, 5/17 (2009), s.19. 
sonra organ bağışında bulunması ile yapılmaktadır. ${ }^{18}$ Ancak 1982 tarihli 2594 sayılı Kanuna göre, kaza ve doğal afet durumlarında vücudun aldığı ölümcül hasardan dolayı yaşamı sona eren bir kişinin eşi, birinci derece yakını ya da reşit çocuklarının yanında bulunmamasında hekimler tarafından belgelenmesi koşuluyla vasiyet ve rıza aranmaksızın organ ve dokuları alınabilmektedir. ${ }^{19}$

Organ nakillerinde verici, canlı ve kadavra olmak üzere ikiye ayrılmaktadır. Canlı kişilerden organ alınması, organ veren kişinin yaşamını riske sokmayacak şekilde çift organlarından birini ya da bir organın bir bölümünü bir başkasına verilmesi ile mümkündür. ${ }^{20}$ Kadavradan organ naklinde ise vericinin tıbben beyin ölümü gerçekleşmiş olması gerekmektedir. Bağışta bulunduğu organlar ihtiyacı olan ve doku uyumu bulunan hastalara nakledilir. ${ }^{21}$ Günümüzde böbrek, akciğer, karaciğer, kalp, kalp kapağı, pankreas, ince bağırsak, kemik, kemik iliği, kan, kornea, deri, sinir, rahim, yüz, kol- bacak gibi yaşamsal öneme sahip pek çok organ ve dokunun nakli yapılmaktadır. ${ }^{22}$ Bireylerin organ bağışında bulunma kararında aile, bilgi düzeyi, din, kültür, bireysel farklılıklar vb. demografik faktörler ile tutum ve davranışlar, özgecilik, inanç, benlik saygısı gibi psikolojik faktörler etkili olmaktadır. ${ }^{23}$

Organ ve doku naklinin sayısı, bir toplumun yasal, etik, tıbbi, sosyal, psikolojik, teknolojik, ekonomik ve dini yönlerden başarısı ile yakından ilgili bir konu olarak değerlendirilmektedir. ${ }^{24}$ Fakat tüm dünyada olduğu gibi ülkemizde de organ bağışında yetersizlik veya yeterli sayıda organın bulunamayışı, organ nakillerinin önünde hala ciddi bir engel oluşturmaktadır. ${ }^{25}$ Toplumun organ bağışına yönelik katılımını arttırmak ve bu konuda sürekliliğinin sağlanması gerekmektedir. Bu amaçla organ bağ1şına istenilen düzeyde ulaşılabilmesi için, bireyleri etkileyen içsel gücün, insandaki en temel olumlu değişkenlerden kabul edilen ve bireylerin davranışlarını etkileyen benlik saygısı ile organ bağışının arasındaki ilişkinin bilinmesi önem arz etmektedir.

18 Levent Yücetin, Nilgün Keçecioğlu ve Fettah Fevzi Ersoy, “Türkiye’de Organ Bağışı ve Nakline Bir Bakış”, Diyaliz Transplantasyon ve Yanık, 14/2 (2003), s.116.

19 Havva Yüksel ve Sadi Evren Seker, “Türkiye’de Organ ve Doku Bağışının Bilgisayarlı Argüman Delfi Yöntemiyle Öngörülmesi”, Uluslararası Sağlık Yönetimi ve Stratejileri Araştırma Dergisi, $2 / 1$ (2016), s.14.

20 Melike Demir Doğan vd., "Üniversite Öğrencilerinin Organ Bağışına Bakış Açısı ve Bilgi Düzeyleri”, Sağllk Bilimleri ve Meslekleri Dergisi, 3/2 (2016), s.100.

21 Selami Kara, Zeliha Salman ve Kurtuluş Öngel, "Süleyman Demirel Üniversitesi Tip Fakültesi Sağlık Personelinin Organ Bağışına Bakışı”, Ankara Sağlık Hizmetleri Dergisi, 11/1 (2012), s.34.

22 Yasin Uzuntarla, “Genç Yaş Grubunun Organ Bağışına Yönelik Düşünce ve Bilgi Düzeylerinin Verilen Eğitime Göre Karşılaştırılması”, Türk Nefroloji Diyaliz ve Transplantasyon Dergisi, 25/3 (2016), s.297. Fatih Sezek vd., "Üniversite Öğrencilerinin Öğrenim Gördükleri Alanlara Göre Organ Nakli ve Bağışı İle İlgili Görüşleri”, Ekev Akademi Dergisi, 19/62 (2015), s.473.

23 Fatma Yaşin Tekizoğlu, “Organ Bağışı: Bireylerin Kararlarını Etkileyen Psikolojik Faktörler”, Muhakeme Dergisi, 1/1 (2018), s.22.

24 Fatih Durur ve Yasemin Akbulut, “Türkiye’de Organ Nakline Yönelik Politikaların Değerlendirilmesi”, Business and Management Studies: An International Journal, 5/3 (2017), s.571. Alptürk Akçöltekin, "Sınıf Öğretmenlerinin Organ Bağışı Tutumlarının Farklı Değişkenler Açısından İncelenmesi”, Karadeniz Uluslararası Bilimsel Dergi, 12/24 (2014), s.53.

25 Ayhan Öznur Cillimoğlu, Sinan Yılmaz ve Mustafa Oğurlu, "Adnan Menderes Üniversitesi Hastanesi Personelinin Organ- Doku Bağışı ve Nakli Hakkındaki Bilgi ve Düşünceleri”, Türk Nefroloji Diyaliz ve Transplantasyon Dergisi, 25/3 (2016), s.2. 


\section{Yöntem}

\section{Araştırmanın Amacı ve Kısıtları}

Çalışmanın amacı üniversite öğrencilerinin benlik saygısı düzeylerinin organ bağışı tutumu ile ilişkisini belirlemektir. Araştırma maddiyat ve zaman kısıtından dolayı Sakarya Üniversitesi İşletme Fakültesi öğrencilerini kapsamaktadır. Çalışmaya katılan gönüllü katılımcılara çalışmanın amacı, toplanan verilerin bilimsel amaçlar dışında kullanılmayacağı ve üçüncü şahıslar ile paylaşılmayacağı konusunda bilgi verilerek ve etik açıklamalar yapılarak onamları sağlanmıştır.

\section{Evren ve Örneklem}

Araştırma evreni Sakarya Üniversitesi İşletme Fakültesinde öğrenim gören üniversite öğrencileri olarak belirlenmiştir. Çalışmanın örneklemini, fakülte öğrencilerinden tesadüfi örnekleme yöntemine göre seçilen 250 öğrenci oluşturmaktadır. Çalışmanın verileri, rızası alınan katılımcılarla yüz yüze anket yöntemiyle elde edilmiştir.

\section{Veri Toplama Araçları}

Çalışmada veri toplama aracı olarak 3 bölümden oluşan bir anket formu kullanılmıştır. Anketin ilk bölümünde sosyo-demografik bilgiler olarak öğrencilerin cinsiyeti, yaşı, sınıfı, organ bağışında bulunup bulunmadığı, çevresinde organ nakli olmuş veya bekleyen yakınlarının olup olmadığı ve organ bağışı ile ilgili bilgileri hangi araçlardan edindiğine ilişkin sorular sorulmuştur.

Anketin ikinci bölümü ise Rosenberg tarafından geliştirilen ve Türkçe uyarlamas1nı Çuhadaroğlu tarafından yapılan "Benlik Saygısı Ölçeği” kullanılmıştır. ${ }^{26}$ Çoktan seçmeli 12 alt kategoriden oluşan ölçekte 63 madde yer almaktadır. Bu çalışmada 10 maddeden oluşan benlik saygısı alt kategorisi kullanılmıştır. Ölçek maddeleri katılımcilar tarafından anket formunda 1'den (Tamamen Katılmıyorum) 4'e (Tamamen Katılıyorum) kadar olan seçeneklerden en uygun olanı işaretlemeleri istenmiştir.

Üçüncü bölümde ise, organ bağışı tutumunu ölçmek için ise Tokay Arğan tarafından geliştirilen "Organ Bağ1şı Tutum Ölçeği” kullanılmıștır. ${ }^{27}$ Ölçek olumlu bakış (8 soru), altruistik değer (5 soru), dince meşrulaştırma (2 soru), dini bakış (2 soru), korku ve endişe ( 3 soru) olmak üzere 5 alt boyuttan oluşmaktadır. Bu ölçek, 1'den 5'e kadar “Tamamen Katılmıyorum”, “Tamamen Katılıyorum” şeklinde puanlanan likert tipinde bir ölçektir.

\section{Verilerin Analizi}

Araştırmadan elde edilen verilerin analizinde tanımlayıcı istatiksel yöntemler, keşfedici faktör analizi, güvenilirlik analizi, bağımsız örneklerde t-testi, tek yönlü varyans

26 Morris Rosenberg, Society and The Adolescent Self-Image, New Jersey: Princeton University Press, 1965. Füsun Çuhadaroğlu, “Adölesanlarda Benlik Saygısı”, Yayımlanmamış Uzmanlık Tezi, Hacettepe Üniversitesi, 1986.

27 Mehpare Tokay Arğan, “Organ Bağışını Artırmada Sosyal Pazarlama Yaklaşımı: Organ Bağışına Yönelik Bir Tutum Araştırması”, Doktora Tezi, Anadolu Üniversitesi, 2007. 
analizi, Mann-Whitney U testi, korelasyon ve regresyon analizleri kullanılmıştır. Analiz sonucunda ulaşılan bulguların $\% 95$ güven aralığında ve $\% 5$ anlamlılık düzeyinde değerlendirildiğini söylemek mümkündür.

\section{Araştırmanın Modeli}

$\mathrm{Bu}$ çalışmada benlik saygısının organ bağışı tutumuna etkisi ve benlik saygısı ile organ bağışı tutumu ilişkisi araştırılacaktır. Çalışmada aynı zamanda kişisel faktörlerin benlik saygısı ve organ bağışı tutumuna etkileri incelenecektir. Bu nedenlerden dolayı araştırmanın hipotezleri aşağıdaki gibidir:

$H_{1}$ : Üniversite öğrencilerinin benlik saygısı düzeyleri organ bağışı tutumlarını etkilemektedir.

$H_{2}$ : Üniversite öğrencilerinin benlik saygısı düzeyleri ile organ bağışı tutumları arasında ilişki vardır.

$H_{3}:$ Üniversite öğrencilerinin kişisel özellikleri organ bağışı tutumlarını etkilemektedir.

$H_{4}$ : Üniversite öğrencilerinin kişisel özellikleri benlik saygısı düzeylerini etkilemektedir.

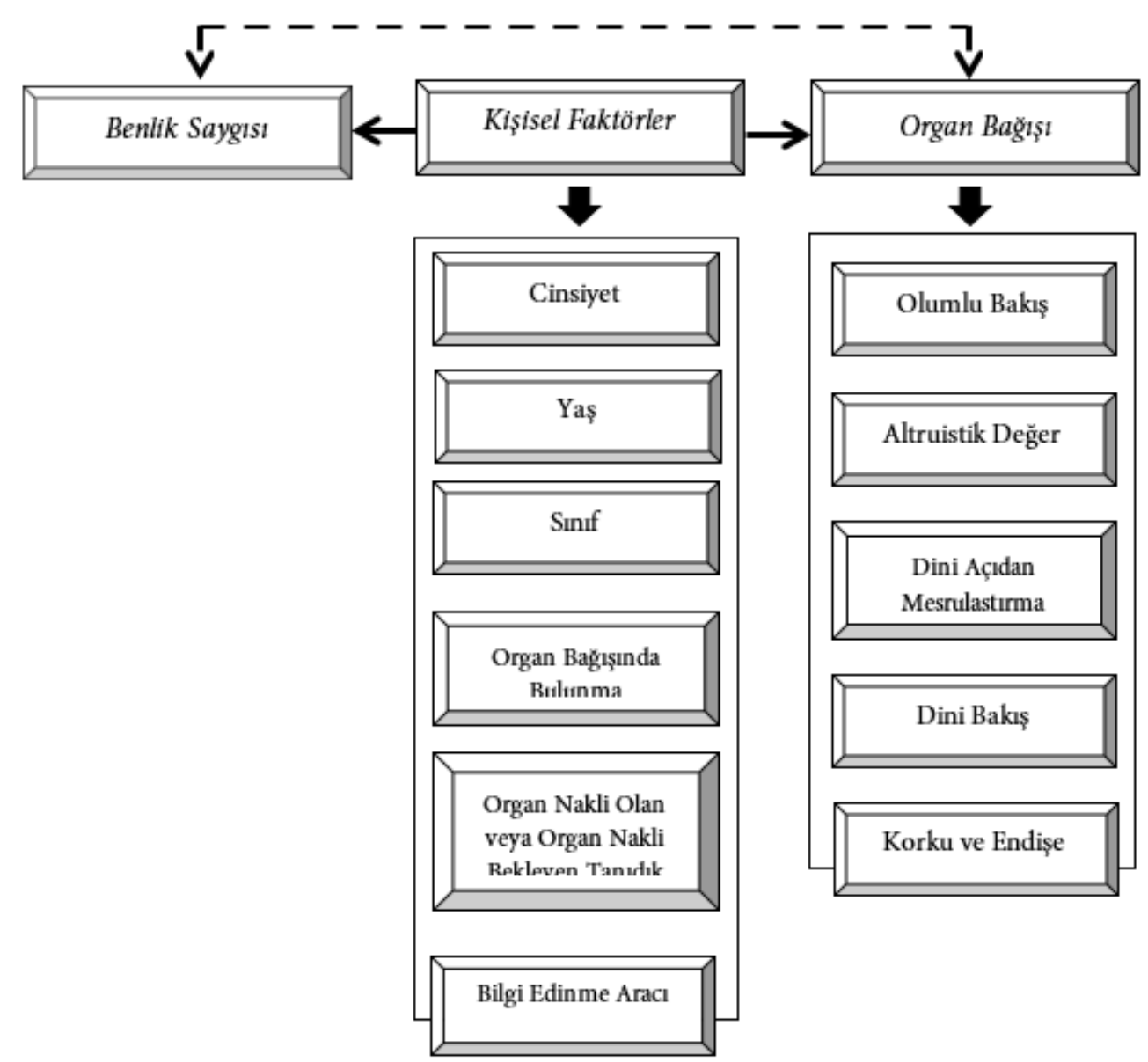

Şekil 1. Araştırma Modeli 


\section{Bulgular}

\section{Katılımcıların Sosyo Demografik Özelliklerine Ait Bulgular}

Çalı̧̧maya katılan bireylerin sosyo demografik özelliklerine ait tanımlayıcı bulgularına bakıldığında, 118'i kadın (\%47,2) ve 132'si erkek (\%52,8) oluşturmaktadır. Katılımciların 18-19 yaş aralığında 50 kişi (\%20,0), 20-22 yaş aralığında 149 kişi $(\% 59,6)$, 23-25 yaş aralığında 51 kişi $(\% 20,4)$ olduğu görülmektedir. Katılımcıların sınıf dağılımı 65 kişi 1. sınıf (\%26,0), 43 kişi 2.sınıf (\%17,2), 83 kişi 3. sınıf (\%33,2), 59 kişi 4. Sınıf $(\% 23,6)$ olduğu; organ bağışında bulunup bulunmama durumu sorulduğunda 5 kişi Evet ( \%2,0), 245 kişi Hayır (\%98,0), çevresinde organ nakli olmuş veya bekleyen yakınının olup olmadığı sorulduğunda ise 23 kişi Evet $(\% 9,2), 227$ kişi Hayır $(\% 90,8)$ olarak cevaplamıştır. Katılımcılara son olarak organ bağışı ile ilgili bilgileri elde etme araçları sorusuna 80 kişi yazılı basın (\%32,0), 139 kişi görsel medya (\%55,6), 31 kişi bilimsel etkinlik $(\% 12,4)$ cevabını vermiştir (Tablo 1).

Tablo 1. Katıllmcılarm Sosyo Demografik Özellikleri $(n=250)$

\begin{tabular}{|c|c|c|c|}
\hline Değişkenler & Kategori & $\begin{array}{c}\text { Frekans } \\
(\mathrm{n})\end{array}$ & $\begin{array}{c}\text { Yüzde } \\
(\%)\end{array}$ \\
\hline \multirow{2}{*}{ Cinsiyet } & Kadın & 118 & 47,2 \\
\hline & Erkek & 132 & 52,8 \\
\hline \multirow{8}{*}{ Yaş } & 18 & 20 & 8,0 \\
\hline & 19 & 30 & 12,0 \\
\hline & 20 & 44 & 17,6 \\
\hline & 21 & 55 & 22,0 \\
\hline & 22 & 50 & 20,0 \\
\hline & 23 & 32 & 12,8 \\
\hline & 24 & 12 & 4,8 \\
\hline & 25 & 7 & 2,8 \\
\hline \multirow{4}{*}{ Sinif } & 1 & 65 & 26,0 \\
\hline & 2 & 43 & 17,2 \\
\hline & 3 & 83 & 33,2 \\
\hline & 4 & 59 & 23,6 \\
\hline \multirow{2}{*}{ Organ bağışında bulundunuz mu? } & Evet & 5 & 2,0 \\
\hline & Hayır & 245 & 98,0 \\
\hline \multirow{2}{*}{ Çevrenizde organ nakli olmuş veya bekleyen yakınınız var mı? } & Evet & 23 & 9,2 \\
\hline & Hayır & 227 & 90,8 \\
\hline \multirow{3}{*}{ Organ bağışı ile ilgili bilgileri elde etme araçları } & $\begin{array}{l}\text { Yazıl1 } \\
\text { Basın }\end{array}$ & 80 & 32,0 \\
\hline & $\begin{array}{l}\text { Görsel } \\
\text { Medya }\end{array}$ & 139 & 55,6 \\
\hline & $\begin{array}{l}\text { Bilimsel } \\
\text { Etkinlik }\end{array}$ & 31 & 12,4 \\
\hline
\end{tabular}




\section{Güvenilirlik Analizi}

Organ bağışı tutumu ölçeğinde güvenilirlik analizi gerçekleştirilmeden önce ters kodlanmış ifadeler yeniden kodlanarak düzeltilmiş ve ölçekte yer alan ifadeler güvenilirlik analizine tabi tutulmuştur. Araştırmada verilerin güvenilirliğini test etmek amacıyla Cronbach's Alpha katsayısından yararlanılmıştır. Cronbach's Alpha katsayısının değerlendirilmesindeki kriterlere bakıldığında; $0,00 \leq a<0,40$ ölçek güvenilir değil, $0,40 \leq a<0,60$ ölçek düşük güvenilirlikte, $0,60 \leq a<0,80$ ölçek oldukça güvenilir, $0,80 \leq \alpha<1,00$ ise ölçek yüksek derecede güvenilir olduğu kabul edilmektedir. ${ }^{28}$

Benlik saygısı ölçeğinin Cronbach's Alpha değeri 0,876; organ bağışı tutum ölçeğinin Cronbach's Alpha değeri 0,886 bulunmuştur. Bu durumda, çalışmada kullanılan ölçeklerden elde edilen verilerin yüksek derecede güvenilir olduğu görülmektedir. Çalışmada kullanılan ölçeklerin geçerlik analizlerini yapmak amacı ile keşfedici faktör analizi kullanılmıştır. Ölçeklere ilişkin faktör analizi sonuçlarına aşağıda yer verilmiştir.

\section{Keşfedici Faktör Analizi}

Faktör analizinde verilerin uygunluğu Kaiser-Meyer Olkin (KMO) katsayısı ve Bartlett Sphericity Testi ile incelenmiştir. KMO değeri olarak 0,80 ve yukarı değerler mükemmel, 0,70-0,80 arası iyi, 0,60-0,70 arası değerler orta, 0,50-0,60 arası kötü ve 0,50 'nin altı ise kabul edilemezdir. ${ }^{29}$ Çalışmada benlik saygısı ölçeğinin KMO katsayısı 0,842; organ bağışı tutumu ölçeğinin KMO katsayısı 0,912 bulunmuştur. Bu sonuçlara göre çalışmanın örneklem büyüklügünün analiz için mükemmel olduğu söylenebilir. Her iki ölçeğin de Bartlett’ testi p değerine bakıldığında değişkenler arası korelâsyonun $\mathrm{p}<0,05$ düzeyinde istatistiksel olarak anlamlı olduğu görülmektedir. Çalışmada faktör sayılarının belirlenmesinde açıklanan varyans dikkate alınmıştır. Çalışmada benlik saygısı ölçeğinin açıklanan toplam varyansı \%47,848 ve organ bağışı tutum ölçeğinin açıklanan toplam varyansı \%72,044 bulunmuştur.

Tablo 2. Benlik Saygısı Ölçeği Faktör Yükleri

\begin{tabular}{|l|l|l|l|r|}
\hline \multicolumn{2}{|l|}{ Kaiser-Meyer-Olkin Measure of Sampling Adequacy } &, 842 \\
\hline Bartlett's Test of Sphericity & Anlamlı & Sig &, 000 \\
\hline Approx Chi-Square & 1396,272 & $d f$ & 45 \\
\hline Açıklanan Toplam Varyans & 47,848 & Cronbach Alpha &, 876 \\
\hline \multicolumn{2}{|l|}{} & $\begin{array}{c}\text { Faktör } \\
\text { Yükü }\end{array}$ & $\begin{array}{c}\text { Açılanan } \\
\text { Varyans }\end{array}$ & $\begin{array}{c}\text { Cronbach } \\
\text { Alfa }\end{array}$ \\
\hline Bazen kesinlikle kendimin bir işe yaramadı̆̆ını &, 742 & 47,848 &, 876 \\
düşünüyorum. & & &
\end{tabular}

28 Şeref Kalaycı, SPSS Uygulamalı Çok Değişkenli İstatistik Teknikleri, Ankara: Asil Yayın Dağıtım, 2005, s.405. 29 Beril Durmuş, Serra Yurtkoru ve Murat Çinko, Sosyal Bilimlerde Spss'le Veri Analizi, İstanbul: Beta Yayınevi, 2013, s.80. 


\begin{tabular}{|l|c|}
\hline Kendime karşı olumlu bir tutum içindeyim. &, 738 \\
\hline $\begin{array}{l}\text { Bazen kendimin hiç de yeterli bir insan olmadı̆̆ını } \\
\text { düşünüyorum. }\end{array}$ &, 736 \\
\hline Genel olarak kendimden memnunum. &, 729 \\
\hline Kendimde gurur duyacak fazla bir şey bulamıyorum. &, 729 \\
\hline $\begin{array}{l}\text { Genelde, kendimi başarısız bir kişi olarak görme } \\
\text { eğilimindeyim. }\end{array}$ &, 690 \\
\hline $\begin{array}{l}\text { Ben de diğer insanların birçoğunun yapabileceği kadar bir } \\
\text { şeyler yapabilirim. }\end{array}$ &, 668 \\
\hline Bazı olumlu özelliklerim olduğunu düşünüyorum. &, 652 \\
\hline Kendimi en az diğer insanlar kadar değerli buluyorum. &, 640 \\
\hline Kendime karşı daha fazla saygı duyabilmeyi isterdim. &, 572 \\
\hline
\end{tabular}

Faktör analizi sonuçlarını değerlendirmede diğer bir temel ölçüt, ölçekte yer alan ve değişkenlerle faktör arasındaki korelasyonlar olarak yorumlanabilen faktör yükleridir. Boyutlar itibari ile ölçeklerin faktör yükleri, açıklanan varyansları ve cronbach's alpha değerleri Tablo 2 ve Tablo 3'te görülmektedir. Faktör analizi sonucunda; benlik saygısı ölçeğinde orijinal haline uygun olarak ifadelerin tek boyut, organ bağışı tutumu ölçeğinin ifadeleri orijinalinde olduğu gibi 5 boyut (olumlu bakış, altruistik değer, dince meşrulaştırma, dini bakış ve korku-endişe) altında toplanmıştır.

Tablo 3. Organ Bă̆ışı Tutum Ölçeği Faktör Yükleri

\begin{tabular}{|c|c|c|c|c|}
\hline \multicolumn{4}{|c|}{ Kaiser-Meyer-Olkin Measure of Sampling Adequacy } & \multirow{2}{*}{,912 } \\
\hline Bartlett's Test of Sphericity & Anlamli & \multicolumn{2}{|l|}{ Sig } & \\
\hline Approx Chi-Square & 3123,387 & \multicolumn{2}{|l|}{$d f$} & 190 \\
\hline Açıklanan Toplam Varyans & 72,044 & \multicolumn{2}{|c|}{ Cronbach Alpha } & ,886 \\
\hline \multicolumn{2}{|l|}{ Faktör 1: Olumlu Bakış } & \begin{tabular}{|c|} 
Faktör \\
Yükü \\
\end{tabular} & $\begin{array}{l}\text { Açıklanan } \\
\text { Varyans }\end{array}$ & $\begin{array}{l}\text { Cronbach } \\
\text { Alfa }\end{array}$ \\
\hline \multicolumn{2}{|c|}{ Organ bağışlamanın iyi bir şey olduğunu düşünüyorum. } &, 834 & \multirow[t]{8}{*}{41,890} & \multirow[t]{8}{*}{,937 } \\
\hline \multicolumn{2}{|c|}{ Organ bağışlamak sosyal bir sorumluluktur. } &, 826 & & \\
\hline \multicolumn{2}{|c|}{$\begin{array}{l}\text { Ölen kişilerin organları yaşam kurtarabilecekken } \\
\text { bağışlanmadığı için ziyan ediliyor }\end{array}$} & 821 & & \\
\hline \multicolumn{2}{|c|}{$\begin{array}{l}\text { Yaşamım tehlikede olsaydı, insanların organ bağışlamasını } \\
\text { isterdim. }\end{array}$} &, 759 & & \\
\hline \multicolumn{2}{|c|}{ Organ bağışlama uygulamasının destekliyorum. } & ,753 & & \\
\hline \multicolumn{2}{|c|}{ Öldükten sonra organlarımın bağışlanmasını isterim. } & ,717 & & \\
\hline \multicolumn{2}{|c|}{$\begin{array}{l}\text { Organ bağışı yapan kişinin organları ihtiyacı olan birine } \\
\text { nakledilirse, ölen kişinin ailesi ve akrabalarının ölüm acısını } \\
\text { hafifletir. }\end{array}$} & ,702 & & \\
\hline \multicolumn{2}{|c|}{$\begin{array}{l}\text { Organ bağışlama benim ahlaki değer ve inançlarıma } \\
\text { uygundur. }\end{array}$} &, 689 & & \\
\hline
\end{tabular}




\begin{tabular}{|c|c|c|c|}
\hline \multicolumn{4}{|l|}{ Faktör 2: Altruistik Değer } \\
\hline Diğer insanlara yardım etmekten hoşlanırım. & 847 & \multirow[t]{5}{*}{52,594} & \multirow[t]{5}{*}{,873 } \\
\hline Diğer insanların mutluluğu beni mutlu ediyor. & 832 & & \\
\hline $\begin{array}{l}\text { Medyada organ bağışından dolayı hayatı kurtulanları } \\
\text { gördüğümde mutlu oluyorum. }\end{array}$ & 803 & & \\
\hline $\begin{array}{l}\text { Bir şeylerin düzelmesi için her insanın organ bağışı } \\
\text { konusunda adım atması gerektiğine inanıyorum. }\end{array}$ & ,626 & & \\
\hline Diğer insanların hayatı beni ilgilendirmiyor. & ,524 & & \\
\hline \multicolumn{4}{|l|}{ Faktör 3: Dini Açıdan Meşrulaştırma } \\
\hline $\begin{array}{l}\text { Organ bağışının dini bakımdan caiz olduğu konusunda } \\
\text { insanlar ikna edilirse bağışta bulunurlar. }\end{array}$ & 834 & \multirow[t]{2}{*}{60,566} & \multirow[t]{2}{*}{,809 } \\
\hline $\begin{array}{l}\text { Diyanet işlerinden organ bağışlamanın caiz olduğuna dair } \\
\text { fetva çıtığı konusunda insanlar bilgilendirilirse organ } \\
\text { bağı̧̧ında bulunurlar. }\end{array}$ & 829 & & \\
\hline \multicolumn{4}{|l|}{ Faktör 4:Dini Bakış } \\
\hline Dinimizin organ bağışına karşı olduğuna inanıyorum. & 815 & \multirow[t]{2}{*}{72,044} & \multirow[t]{2}{*}{,688 } \\
\hline Dinimize göre ölen kişinin organlarının tam olması gerekir. & ,770 & & \\
\hline \multicolumn{4}{|l|}{ Faktör 5: Korku ve Endişe } \\
\hline $\begin{array}{l}\text { Organlarımı bağışlarsam, hastalandığımda bazı doktorların } \\
\text { organlarımın başkalarına nakledilmesi için yeterli tıbbi } \\
\text { müdahaleyi yapmayacaklarından korkarım. }\end{array}$ & 811 & 66,964 & ,674 \\
\hline $\begin{array}{l}\text { Organ mafyasının varlığı organ bağışında bulunmak } \\
\text { isteyenleri korkutur. }\end{array}$ &, 804 & & \\
\hline $\begin{array}{l}\text { Organ bağışında bulunma fikrini düşündüğümde aklıma } \\
\text { hemen ölüm korkusu geliyor. }\end{array}$ & ,648 & & \\
\hline
\end{tabular}

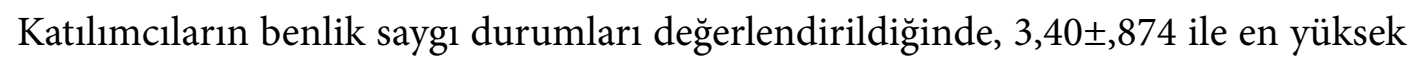
değeri "Kendimi en az diğer insanlar kadar değerli buluyorum" ifadesine verilen ce-


bilmeyi isterdim" sorusuna verilen cevaplar almıştır (Tablo 4).

Tablo 4. Benlik Saygısı Ölçeği Ortalama ve Standart Sapma Değerleri

\begin{tabular}{|l|c|c|}
\hline İfadeler & Ortalama & $\begin{array}{c}\text { Standart } \\
\text { Sapma }\end{array}$ \\
\hline Kendimi en az diğer insanlar kadar değerli buluyorum. & 3,40 & 0,874 \\
\hline Bazı olumlu özelliklerim olduğunu düşünüyorum. & 3,33 & 0,834 \\
\hline $\begin{array}{l}\text { Ben de diğer insanların birçoğunun yapabileceği kadar bir şeyler } \\
\text { yapabilirim. }\end{array}$ & 3,30 & 0,767 \\
\hline Genelde, kendimi başarısız bir kişi olarak görme eğilimindeyim. & 3,21 & 0,715 \\
\hline Bazen kesinlikle kendimin bir işe yaramadığımı düşünüyorum. & 3,21 & 0,805 \\
\hline Kendimde gurur duyacak fazla bir şey bulamıorum. & 3,16 & 0,754 \\
\hline Bazen kendimin hiç de yeterli bir insan olmadığımı düşünüyorum. & 3,16 & 0,799 \\
\hline Kendime karşı olumlu bir tutum içindeyim. & 3,15 & 0,787 \\
\hline Genel olarak kendimden memnunum. & 3,15 & 0,827 \\
\hline Kendime karşı daha fazla saygı duyabilmeyi isterdim. & 2,80 & 0,881 \\
\hline
\end{tabular}




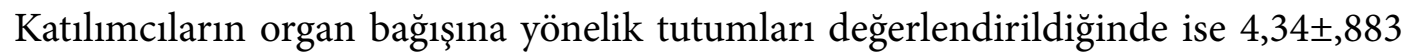
ile en yüksek değeri "Diğer insanlara yardım etmekten hoşlanırım." değişkenine ve-

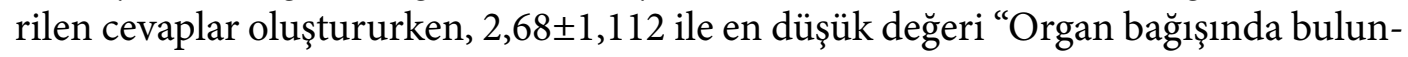
ma fikrini düşündüğümde aklıma hemen ölüm korkusu geliyor.” sorusuna verilen cevaplar oluşturulmaktadır (Tablo 5).

Tablo 5. Organ Bağışı Tutumu Ölçeği Ortalama ve Standart Sapma Değerleri

\begin{tabular}{|l|c|c|}
\hline Ifadeler & Ortalama & $\begin{array}{c}\text { Standart } \\
\text { Sapma }\end{array}$ \\
\hline Diğer insanlara yardım etmekten hoşlanırım. & 4,34 & 0,883 \\
\hline $\begin{array}{l}\text { Medyada organ bağışından dolayı hayatı kurtulanları gördüğümde } \\
\text { mutlu oluyorum. }\end{array}$ & 4,28 & 0,915 \\
\hline Organ bağışlama uygulamasının destekliyorum. & 4,16 & 0,975 \\
\hline Diğer insanların mutluluğu beni mutlu ediyor. & 4,14 & 0,963 \\
\hline Yaşamım tehlikede olsaydı, insanların organ bağışlamasını isterdim. & 4,14 & 0,947 \\
\hline Organ bağışlamanın iyi bir şey olduğunu düşünüyorum. & 4,05 & 0,970 \\
\hline Organ bağışlama benim ahlaki değer ve inançlarıma uygundur. & 3,96 & 0,993 \\
\hline Organ bağışlamak sosyal bir sorumluluktur. & 3,92 & 1,009 \\
\hline $\begin{array}{l}\text { Bir şeylerin düzelmesi için her insanın organ bağışı konusunda adım } \\
\text { atması gerektiğine inanıyorum. }\end{array}$ & 3,92 & 1,048 \\
\hline Diğer insanların hayatı beni ilgilendirmiyor. & 3,92 & 0,815 \\
\hline Öldükten sonra organlarımın bağı̧̧lanmasını isterim. & 3,90 & 1,078 \\
\hline $\begin{array}{l}\text { Ölen kişilerin organları yaşam kurtarabilecekken bağışlanmadığı için } \\
\text { ziyan ediliyor. }\end{array}$ & 3,88 & 0,996 \\
\hline $\begin{array}{l}\text { Diyanet işlerinden organ bağışlamanın caiz olduğuna dair fetva } \\
\text { çıtığı konusunda insanlar bilgilendirilirse organ bağışında } \\
\text { bulunurlar. }\end{array}$ & 3,78 & 1,021 \\
\hline Dinimizin organ bağışına karşı olduğuna inanıyorum. & 3,77 & 1,148 \\
\hline $\begin{array}{l}\text { Organ bağışının dini bakımdan caiz olduğu konusunda insanlar ikna } \\
\text { edilirse bağışta bulunurlar. }\end{array}$ & 3,72 & 1,045 \\
\hline $\begin{array}{l}\text { Organ bağışı yapan kiş̧inin organları ihtiyacı olan birine nakledilirse, } \\
\text { ölen kişinin ailesi ve akrabalarının ölüm acısını hafifletir. }\end{array}$ & 3,55 & 0,905 \\
\hline Dinimize göre ölen kişinin organlarının tam olması gerekir. & 3,45 & 1,172 \\
\hline $\begin{array}{l}\text { Organ mafyasının varlı̆ı̆ organ bağışında bulunmak isteyenleri } \\
\text { korkutur. }\end{array}$ & 3,12 & 1,174 \\
\hline $\begin{array}{l}\text { Organlarımı bağışlarsam, hastalandığımda bazı doktorların } \\
\text { organlarımın başkalarına nakledilmesi için yeterli tıbbi müdahaleyi } \\
\text { yapmayacaklarından korkarım. }\end{array}$ & 3,00 & 1,028 \\
\hline $\begin{array}{l}\text { Organ bağışında bulunma fikrini düşündüğümde aklıma hemen } \\
\text { ölüm korkusu geliyor. }\end{array}$ & 2,68 & 1,112 \\
\hline
\end{tabular}




\section{Kişisel Özellikler ile Benlik Saygısı ve Organ Bağışı Tutumu Illişkisi}

Sosyo-demografik değişkenler açısından benlik saygısı ve organ bağışı tutumu açısından anlamlı bir farklılaşmanın olup olmadığı belirlenmeye çalışılmıştır. Bu amaçla bağımsız örneklem testi ve tek yönlü varyans analizleri yapılmıştır. Yapılan analiz sonucunda, katılımcıların cinsiyetleri ile benlik saygısı üzerinde fark bulunamamışken, organ bağışı tutumu ölçeğinin alt boyutu olan altruistik değer arasında istatistiksel açıdan anlamlı bir farklılık gösterdiği tespit edilmiştir ( $\mathrm{p}=, 002 ; \mathrm{p}<, 005) . \mathrm{Bu}$ durumda kadınların erkeklere oranla daha yüksek altruistik değere sahip olduğu saptanmıştır $(4,2712 \pm 0,62019)$ (Tablo 6).

Tablo 6. Cinsiyet Değişkeni Bağımsız Örneklem T Testi Bulguları

\begin{tabular}{|c|c|c|c|c|c|c|}
\hline \multirow{3}{*}{ Benlik Saygısı } & Cinsiyet & $n$ & Ortalama & $\begin{array}{c}\text { Standart } \\
\text { Sapma }\end{array}$ & $F$ & $p$ \\
\hline & Kadın & 118 & 3,19 & 0,527 & \multirow{2}{*}{2,043} & \multirow{2}{*}{,853 } \\
\hline & Erkek & 132 & 3,18 & 0,579 & & \\
\hline \multirow{2}{*}{ Olumlu Bakış } & Kadın & 118 & 4,00 & 0,787 & \multirow{2}{*}{, 758} & \multirow{2}{*}{,323 } \\
\hline & Erkek & 132 & 3,89 & 0,851 & & \\
\hline \multirow{2}{*}{ Altruistik Değer } & Kadın & 118 & 4,27 & 0,620 & \multirow{2}{*}{4,783} & \multirow{2}{*}{, 002} \\
\hline & Erkek & 132 & 3,99 & 0,838 & & \\
\hline \multirow{2}{*}{$\begin{array}{c}\text { Dince } \\
\text { Meşrulaştırma }\end{array}$} & Kadın & 118 & 3,79 & 0,892 & \multirow{2}{*}{1,549} & \multirow{2}{*}{, 504} \\
\hline & Erkek & 132 & 3,71 & 0,994 & & \\
\hline \multirow{2}{*}{ Dini Bakış } & Kadın & 118 & 3,70 & 1,007 & \multirow{2}{*}{, 007} & \multirow{2}{*}{, 199 } \\
\hline & Erkek & 132 & 3,53 & 1,016 & & \\
\hline \multirow{2}{*}{ Korku ve Endişe } & Kadın & 118 & 2,90 & 0,750 & \multirow{2}{*}{5,305} & \multirow{2}{*}{, 590} \\
\hline & Erkek & 132 & 2,96 & 0,951 & & \\
\hline \multirow{2}{*}{ Organ Bağış Tutum } & Kadın & 118 & 3,85 & 0,520 & \multirow{2}{*}{1,330} & \multirow{2}{*}{,075 } \\
\hline & Erkek & 132 & 3,72 & 0,606 & & \\
\hline
\end{tabular}

Organ bağışına bulunup bulunmama durumuna göre benlik saygısı ve organ bağı̣ıı tutumunun farklılaşıp farklılaşmadığı test etmek için Mann-Whitney U Testi uygulanmıştır (Tablo 7). Analiz sonucuna göre benlik saygısı düzeyi ve organ bağışı tutumunun, organ bağışında bulunma durumu açısından anlamlı bir farklılık oluşturmadığg görülmüsstür ( $\mathrm{p}>, 05)$. 
Tablo 7. Organ Bağışında Bulunup- Bulunmama Değiş̧keni Mann-Whitney U Testi Bulguları

\begin{tabular}{|c|c|c|c|c|c|c|}
\hline \multirow{3}{*}{ Benlik Saygısı } & $\begin{array}{c}\text { Organ Bă̆ışında } \\
\text { Bulunup-Bulunmama }\end{array}$ & $n$ & $\begin{array}{c}\text { Sira } \\
\text { Ortalama }\end{array}$ & $\begin{array}{c}\text { Sira } \\
\text { Toplamı }\end{array}$ & $U$ & $p$ \\
\hline & Evet & 5 & 114,00 & 570,00 & \multirow{2}{*}{555,00} & \multirow{2}{*}{,719 } \\
\hline & Hayır & 245 & 125,73 & 30805,00 & & \\
\hline \multirow{2}{*}{ Olumlu Bakış } & Evet & 5 & 155,60 & 778,00 & \multirow{2}{*}{462,00} & \multirow{2}{*}{,346 } \\
\hline & Hayır & 245 & 124,89 & 30597,00 & & \\
\hline \multirow{2}{*}{ Altruistik Değer } & Evet & 5 & 155,50 & 777,50 & \multirow{2}{*}{462,0} & \multirow{2}{*}{,346 } \\
\hline & Hayır & 245 & 124,89 & 30597,50 & & \\
\hline \multirow{2}{*}{ Dince Meşrulaştırma } & Evet & 5 & 122,70 & 613,50 & \multirow{2}{*}{598,50} & \multirow{2}{*}{,928 } \\
\hline & Hayır & 245 & 125,56 & 30761,50 & & \\
\hline \multirow{2}{*}{ Dini Bakış } & Evet & 5 & 181,10 & 905,50 & \multirow{2}{*}{334,50} & \multirow{2}{*}{, 077} \\
\hline & Hayır & 245 & 124,37 & 30469,50 & & \\
\hline \multirow{2}{*}{ Korku ve Endişe } & Evet & 5 & 63,90 & 319,50 & \multirow{2}{*}{304,50} & \multirow{2}{*}{,053 } \\
\hline & Hayır & 245 & 126,76 & 31055,50 & & \\
\hline \multirow{2}{*}{ Organ Bağış Tutum } & Evet & 5 & 153,90 & 769,50 & \multirow{2}{*}{470,50} & \multirow{2}{*}{,375 } \\
\hline & Hayır & 245 & 124,92 & 30605,50 & & \\
\hline
\end{tabular}

Herhangi bir yakını organ bağışında bulunan veya bekleyen olma durumuna göre benlik saygısı ve organ bağışı tutumunun farklılaşıp farklılaşmadığı test etmek için Mann-Whitney U Testi uygulanmıştır (Tablo 8). Analiz sonucuna göre benlik saygısı düzeyi ve organ bağışı tutumunun, herhangi bir yakını organ bağışında bulunma veya herhangi bir yakını organ bağışı bekleme durumu açısından anlamlı bir farkl1lık oluşturmadığı görülmüştür ( $\mathrm{p}>, 05)$.

Tablo 8. Organ Bağışı Olan veya Bekleyen Yakını Olma Değişkeni Bağımsız Örneklem T Testi Bulguları

\begin{tabular}{|c|c|c|c|c|c|c|}
\hline \multirow{3}{*}{ Benlik Saygısı } & Organ Bağışı Olma & $n$ & $\begin{array}{c}\text { Sira } \\
\text { Ortalama }\end{array}$ & $\begin{array}{c}\text { Sira } \\
\text { Toplamı }\end{array}$ & $U$ & $p$ \\
\hline & Evet & 23 & 124,46 & 2862,50 & \multirow{2}{*}{2586.50} & \multirow{2}{*}{,942 } \\
\hline & Hayır & 227 & 125,61 & 28512,50 & & \\
\hline \multirow{2}{*}{ Olumlu Bakış } & Evet & 23 & 126,39 & 2907,00 & \multirow{2}{*}{2590.00} & \multirow{2}{*}{,950 } \\
\hline & Hayır & 227 & 125,41 & 28468,00 & & \\
\hline \multirow{2}{*}{ Altruistik Değer } & Evet & 23 & 125,85 & 2894,50 & \multirow{2}{*}{2602.50} & \multirow{2}{*}{,981 } \\
\hline & Hayır & 227 & 125,46 & 28480,50 & & \\
\hline \multirow{2}{*}{ Dince Meşrulaştırma } & Evet & 23 & 108,61 & 2498,00 & \multirow{2}{*}{2222.00} & \multirow{2}{*}{224} \\
\hline & Hayır & 227 & 127,21 & 28877,00 & & \\
\hline \multirow{2}{*}{ Dini Bakış } & Evet & 23 & 146,02 & 3358,50 & \multirow{2}{*}{2138.50} & \multirow{2}{*}{, 146} \\
\hline & Hayır & 227 & 123,42 & 28016,50 & & \\
\hline \multirow{2}{*}{ Korku ve Endişe } & Evet & 23 & 116,41 & 2677,50 & \multirow{2}{*}{2401.50} & \multirow{2}{*}{, 524} \\
\hline & Hayır & 227 & 126,42 & 28697,50 & & \\
\hline \multirow{2}{*}{ Organ Bağış Tutum } & Evet & 23 & 123,17 & 2833,00 & \multirow{2}{*}{2557.00} & \multirow{2}{*}{,871 } \\
\hline & Hayır & 227 & 125,74 & 28542,00 & & \\
\hline
\end{tabular}


Yaş değişkeniyle ilgili sonuçlara bakıldığında; organ bağışı tutumunun alt boyutu olan altruistik değerin yaşa göre istatistiksel açıdan anlamlı bir fark bulunmuştur $(\mathrm{p}=, 027 ; \mathrm{p}<0,05)$. Bulgulara göre bu farklılık 18-19 yaş arasındaki ile 23-25 yaş arasindaki bireyler arasında kaynaklanmaktadır. 18-19 yaş arasında olan bireylerin altruistik değerleri, 20-22 yaş arasında olan ve 23-25 yaşında olan bireylere oranla daha yüksektir (Tablo 9).

Tablo 9. Yaş Değişkeni Tek Yönlü Varyans Analizi Bulguları

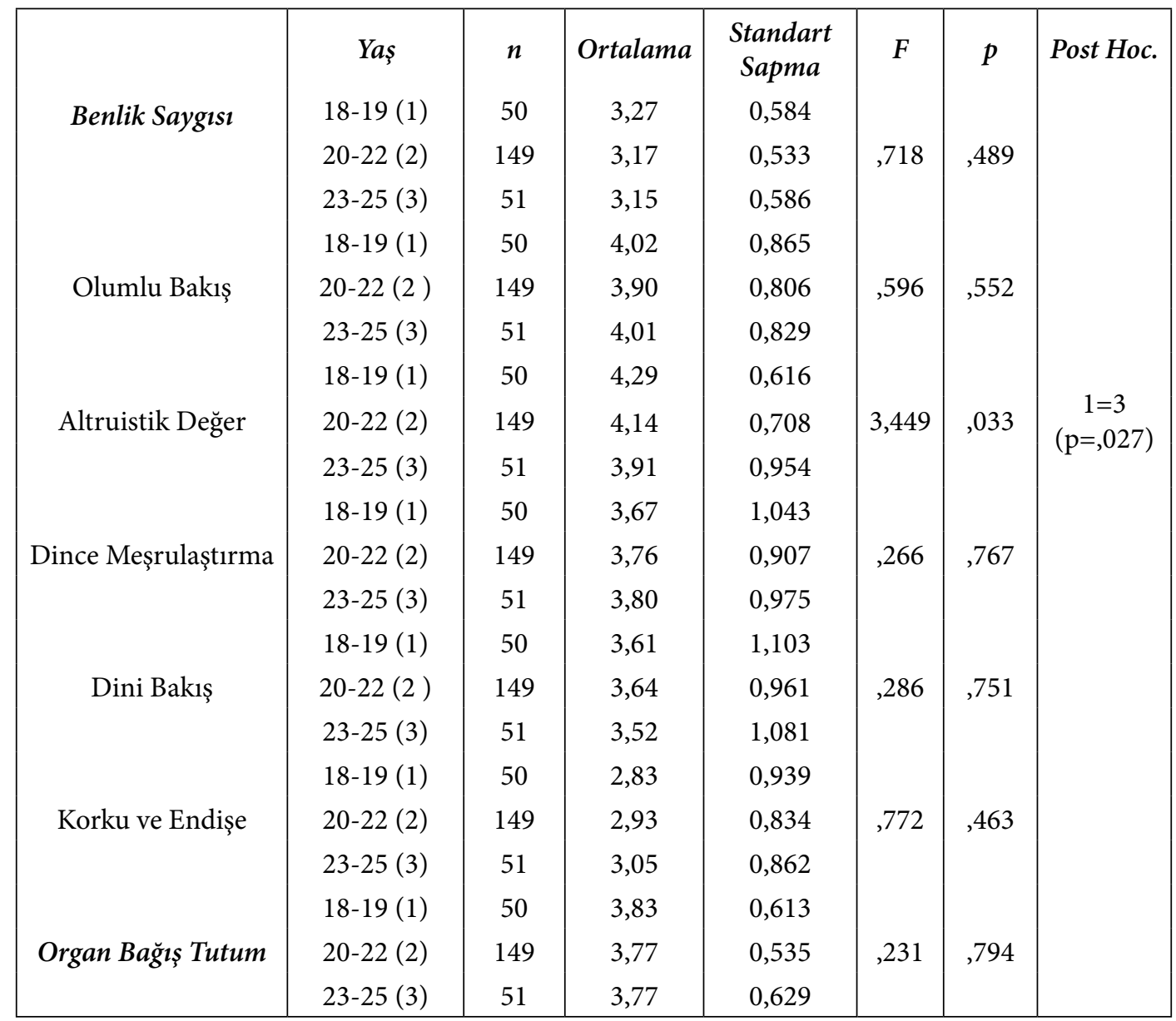

Sınıf değişkeni ile ilgili sonuçlara bakıldığında; Altruistik değer olarak isimlendirilen faktör ile sınıf arasında istatistiksel olarak anlamlı bir farklılık göstermektedir $(\mathrm{p}=, 024 ; \mathrm{p}<0,05)$. Bu farklılığın 1. ve 4. sınıftaki öğrenciler arasında kaynaklanmaktadır. Buna göre, 1. sınıfta olan öğrencilerin diğer sınıftaki öğrencilere oranla daha yüksek altruistik değere sahip olduğu görülmektedir (Tablo 10). 
Tablo 10. Sinıf Değişkeni Tek Yönlü Varyans Analizi Bulguları

\begin{tabular}{|c|c|c|c|c|c|c|c|}
\hline \multirow{5}{*}{ Benlik Saygısı } & Sinif & $n$ & Ortalama & $\begin{array}{c}\text { Standart } \\
\text { Sapma }\end{array}$ & $F$ & $p$ & \multirow[t]{10}{*}{ Post Hoc. } \\
\hline & 1 & 65 & 3,29 & 0,546 & \multirow{5}{*}{1,752} & \multirow{5}{*}{,157 } & \\
\hline & 2 & 43 & 3,07 & 0,605 & & & \\
\hline & 3 & 83 & 3,22 & 0,468 & & & \\
\hline & 4 & 59 & 3,12 & 0,620 & & & \\
\hline \multirow{5}{*}{ Olumlu Bakış } & 1 & 65 & 4,09 & 0,776 & & & \\
\hline & 2 & 43 & 3,83 & 0,987 & \multirow{4}{*}{1,272} & \multirow{4}{*}{,284 } & \\
\hline & 3 & 83 & 3,87 & 0,817 & & & \\
\hline & 4 & 59 & 3,97 & 0,734 & & & \\
\hline & 1 & 65 & 4,30 & 0,595 & & & \\
\hline \multirow{4}{*}{$\begin{array}{l}\text { Altruistik } \\
\text { Değer }\end{array}$} & 2 & 43 & 4,11 & 0,919 & \multirow{4}{*}{2,733} & \multirow{4}{*}{,044 } & $1=4$ \\
\hline & 3 & 83 & 4,14 & 0,656 & & & $(\mathrm{p}=, 024)$ \\
\hline & 4 & 59 & 3,91 & 0,872 & & & \\
\hline & 1 & 65 & 3,78 & 0,940 & & & \\
\hline \multirow{4}{*}{$\begin{array}{l}\text { Dince Meşru- } \\
\text { laştırma }\end{array}$} & 2 & 43 & 3,65 & 1,099 & \multirow{4}{*}{,379 } & \multirow{4}{*}{,769 } & \\
\hline & 3 & 83 & 3,72 & 1,016 & & & \\
\hline & 4 & 59 & 3,84 & 0,722 & & & \\
\hline & 1 & 65 & 3,63 & 1,108 & & & \\
\hline \multirow{4}{*}{ Dini Bakış } & 2 & 43 & 3,80 & 1,019 & \multirow{4}{*}{, 760} & \multirow{4}{*}{, 518} & \\
\hline & 3 & 83 & 3,57 & 0,931 & & & \\
\hline & 4 & 59 & 3,51 & 1,015 & & & \\
\hline & 1 & 65 & 2,84 & 0,937 & & & \\
\hline \multirow{4}{*}{$\begin{array}{l}\text { Korku ve } \\
\text { Endişe }\end{array}$} & 2 & 43 & 2,99 & 0,868 & \multirow{4}{*}{,429 } & \multirow{4}{*}{,732 } & \\
\hline & 3 & 83 & 2,99 & 0,744 & & & \\
\hline & 4 & 59 & 2,92 & 0,929 & & & \\
\hline & 1 & 65 & 3,88 & 0,547 & & & \\
\hline \multirow{3}{*}{$\begin{array}{l}\text { Organ Bağış } \\
\text { Tutum }\end{array}$} & 2 & 43 & 3,75 & 0,715 & \multirow{3}{*}{,804 } & \multirow{3}{*}{ 493 } & \\
\hline & 3 & 83 & 3,76 & 0,528 & & & \\
\hline & 4 & 59 & 3,74 & 0,532 & & & \\
\hline
\end{tabular}

Organ bağışı ile ilgili bilgileri ulaşma araçları değişkeniyle ilgili sonuçlara bakıldığında; benlik saygısı düzeyi ve organ bağışı tutumu üzerinde herhangi bir farklılık bulunmadığı tespit edilmiştir (Tablo 11). 
Tablo 11. Organ Bağışı ile İlgili Bilgi Kaynă̆ı Değisşkeni Tek Yönlü Varyans Analizi Bulguları

\begin{tabular}{|c|c|c|c|c|c|c|}
\hline \multirow{4}{*}{ Benlik Saygısı } & Bilgi Kaynă̆ı & $n$ & Ortalama & Standart Sapma & $F$ & $p$ \\
\hline & Yazılı Basın & 80 & 3,18 & 0,551 & & \\
\hline & Görsel Medya & 139 & 3,17 & 0,568 &, 581 &, 560 \\
\hline & Bilimsel Etkinlik & 31 & 3,29 & 0,502 & & \\
\hline \multirow{3}{*}{ Olumlu Bakış } & Yazılı Basın & 80 & 3,96 & 0,764 & & \\
\hline & Görsel Medya & 139 & 3,96 & 0,869 & 491 & 613 \\
\hline & Bilimsel Etkinlik & 31 & 3,81 & 0,750 & & \\
\hline \multirow{3}{*}{ Altruistik Değer } & Yazılı Basın & 80 & 4,21 & 0,613 & & \\
\hline & Görsel Medya & 139 & 4,07 & 0,853 & ,866 & ,422 \\
\hline & Bilimsel Etkinlik & 31 & 4,12 & 0,608 & & \\
\hline \multirow{3}{*}{$\begin{array}{c}\text { Dince } \\
\text { Meşrulaştırma }\end{array}$} & Yazılı Basın & 80 & 3,81 & 0,919 & & \\
\hline & Görsel Medya & 139 & 3,74 & 1,008 &, 336 & ,715 \\
\hline & Bilimsel Etkinlik & 31 & 3,65 & 0,721 & & \\
\hline \multirow{3}{*}{ Dini Bakış } & Yazılı Basın & 80 & 3,74 & 0,987 & & \\
\hline & Görsel Medya & 139 & 3,59 & 1,056 & 1,321 & ,269 \\
\hline & Bilimsel Etkinlik & 31 & 3,40 & 0,851 & & \\
\hline \multirow{3}{*}{ Korku ve Endişe } & Yazılı Basın & 80 & 3,01 & 0,934 & & \\
\hline & Görsel Medya & 139 & 2,90 & 0,852 & ,438 & ,646 \\
\hline & Bilimsel Etkinlik & 31 & 2,88 & 0,697 & & \\
\hline \multirow{3}{*}{$\begin{array}{l}\text { Organ Bağıs } \\
\text { Tutum }\end{array}$} & Yazılı Basın & 80 & 3,84 & 0,498 & & \\
\hline & Görsel Medya & 139 & 3,77 & 0,629 & 900 & ,408 \\
\hline & Bilimsel Etkinlik & 31 & 3,69 & 0,441 & & \\
\hline
\end{tabular}

\section{Benlik Saygısı ve Organ Bağışı Tutumu Arasındaki Illişki}

Çalışmada incelenen ölçekler arasında istatistiksel açıdan anlamlı bir ilişki olup olmadığı korelasyon analizinden yararlanılarak test edilmiştir. Elde edilen bulgulara göre, benlik saygısı ile organ bağışı tutumu arasında istatistiksel açıdan anlamlı, pozitif yönde ve orta seviyede bir ilişki olduğu bulunmuştur $(r=, 308)$. Bu durumda öğrencilerin benlik saygısı düzeyleri artıkça organ bağışı tutum düzeylerinin de artacağı söylenebilir (Tablo 12).

Organ bağışı ile ilgili tutumlar konusunda ortaya çıkan beş faktörün kendi aralarındaki korelasyon matrisi analiz edildiğinde; korku ve endişe faktörü ile diğer faktörler arasında negatif yönlü bir ilişki saptanmıştır. Geriye kalan tüm faktörler arasında da pozitif yönlü bir ilişkinin olduğu ortaya çıkmaktadır (Tablo 12).

Tablo 12. Benlik Saygısı ve Organ Bağışı Tutumu Arasındaki İlişki

\begin{tabular}{|l|l|l|r|r|r|r|r|}
\hline & \multicolumn{1}{|c|}{$\mathbf{1}$} & \multicolumn{1}{c|}{$\mathbf{1 a}$} & $\mathbf{1 b}$ & $\mathbf{1 c}$ & $\mathbf{1 d}$ & $\mathbf{1 e}$ & $\mathbf{2}$ \\
\hline Benlik Saygısı (1) & 1 & & & & & & \\
\hline Olumlu Bakı̧ (1a) &, $267^{* *}$ & 1 & & & & & \\
\hline Altruistik Değer (1b) &, $347^{* *}$ &, $659^{* *}$ & 1 & & & & \\
\hline
\end{tabular}




\begin{tabular}{|l|r|r|r|r|r|r|r|}
\hline Dince Meşrulaştırma (1c) &, $217^{* *}$ &, $503^{* *}$ &, $360^{* *}$ & 1 & & & \\
\hline Dini Bakış (1d) &, $160^{*}$ &, $392^{* *}$ &, $340^{* *}$ &, $135^{*}$ & 1 & & \\
\hline Korku ve Endişe (1e) & -.116 & -.086 & -.120 & -.031 &,$- 351^{* *}$ & 1 & \\
\hline Organ Bağış Tutumu (2) &, $308^{* *}$ &, $930^{* *}$ &, $805^{* *}$ &, $593^{* *}$ &, $460^{* *}$ & .070 & 1 \\
\hline
\end{tabular}

${ }^{*} \mathrm{p}<0,01$ düzeyinde anlamlı korelasyon, ${ }^{\star} \mathrm{p}<0,05$ düzeyinde anlamlı korelasyon

\section{Benlik Saygısının Organ Bağışı Tutumuna Olan Etkisi}

Benlik saygısının organ bağışı tutumuna olan etkisinin ölçümü için yapılan regresyon analizi Tablo 13'te verilmiştir. Benlik saygısının organ bağışı tutumu üzerinde pozitif yönde etkisi olduğu saptanmıştır $(\beta=, 308)$. Analiz sonuçlarına göre kurulan regresyon modeli istatistiksel açıdan anlamlıdır $(\mathrm{F}=25,901)(\mathrm{p}=, 000 ; \mathrm{p}<0,05) . \mathrm{Bu}$ durumda, benlik saygısının organ bağışı tutumunu istatistiksel açıdan anlamlı ve pozitif yönde etkisi bulunmaktadır. Tabloda yer alan 0,095'lik düzeltilmiş $\mathrm{R}^{2}$ değeri benlik saygısı değerinde yaşanan \% 9,5’lik bir değişimin organ bağışı tutumunu olumlu etkisi vasıtasıyla açıklandığını göstermektedir. Bu doğrultuda, öğrencilerin benlik saygısı düzeyleri arttıkça organ bağışı tutum düzeylerinin de etkileneceği söylenebilir (Tablo 13).

Tablo 13. Benlik Saygısının Organ Bağışı Tutumuna Olan Etkisi

\begin{tabular}{|c|c|c|c|c|c|}
\hline \multirow[t]{2}{*}{ Model-1 } & \multicolumn{2}{|c|}{$\begin{array}{c}\text { Standardize } \\
\text { Edilmemiş } \\
\text { Katsayılar }\end{array}$} & \multirow{2}{*}{$\begin{array}{c}\begin{array}{c}\text { Standardize } \\
\text { Edilmiş } \\
\text { Katsayılar }\end{array} \\
\text { Beta }\end{array}$} & \multirow[t]{2}{*}{$\mathbf{t}$} & \multirow[t]{2}{*}{$\mathbf{p}$} \\
\hline & Beta & Std. Hata & & & \\
\hline Sabit & 2,776 & ,201 & & 13,816 &, 000 \\
\hline Benlik Saygısı &, 316 & ,062 & ,308 & 5,089 & ,000 \\
\hline
\end{tabular}

a Predictors (Bağımsız Değişken): Benlik Saygısı

b Dependent Variable (Bağımlı Değişken): Organ Bağışı Tutumu

\section{Tartışma ve Sonuç}

Araştırma bulgularından ilki altruistik değer ile cinsiyet arasında anlamlı bir farklılık bulunmuştur. Kız öğrencilerin altruistik değerleri erkek öğrencilere göre daha yüksek olduğu saptanmıştır. Bu bulgu literatürde yer alan ilgili araştırmaların bulguları ile büyük ölçüde örtüşmektedir. ${ }^{30}$ Yaygın cinsiyet rolü görüşüne göre, kadınların dış olaylara erkeklerden daha çok duygusal tepki gösterdikleri ve diğerlerinin duygularını daha çok dikkate alacak şekilde davranışta bulundukları söylenilebilir.

30 Muhammet Cevat Acar ve Hıdır Apak, "Sosyal Hizmet Bölümü Öğrencilerinin Empatik Eğilimleri ile Özgecilik Düzeyleri Arasındaki İlişkinin İncelenmesi”, Toplum ve Sosyal Hizmet, 28/1 (2017), s.100. Zeynep Başerer ve İbrahim Kısaç, "Özgeci Davranışın Psikolojik İyi Oluş ve Çeşitli Demografik Değişkenlere Göre İncelenmesi: Erzurum İli Örneği”, Akademik Sosyal Araştırmalar Dergisi, 5/56 (2017), s.587. Çiğdem Demir Çelebi, Halil Eksi ve Mine Sayın, "Üniversite Öğrencilerinin Özgecilik ve Otantiklik Seviyeleri Arasındaki İlişkinin İncelenmesi”, Değerler Eğitimi Dergisi, 14/32 (2016), s.88. Meredith McGinley ve Gustavo Carlo, "Two Sides of The Same Coin? The Relations Between Prosocial and Physically Aggressive Behaviors", Journal of Youth and Adolescence, 36/3 2007, s.337. J. Philippe Rushton vd., "Altruism and Aggression: The Heritability of Individual Differences", Journal of Personality and Social Psychology, 50/6 (1986), s.1194. 
İkinci bir bulgu olan sınıf düzeyi ile altruistik değer arasında anlamlı bir farklılık bulunmuştur. 1. sınıftaki öğrencilerin 4. sınıftaki öğrencilere göre daha yüksek altruistik değerleri sahip oldukları saptanmıştır. Literatür incelendiğinde Kasapoğlu’nun çalışmasında 3. sınıf öğrencilerinin altruistik değerleri 1.sınıf öğrencilerine göre daha yüksek çıkmıştır. ${ }^{31}$ Ancak Ak’n çalışmasında 1. ve 2. sınıf öğrencilerinin 3. ve 4. sınıf öğrencilerine göre altruistik değerleri daha yüksek bulunmuştur. Buna göre öğrencilerin sınıf düzeyi arttıkça altruistik değerlerinin azaldığ 1 çıkarılmaktadır. ${ }^{32}$ Ayrıca Akbaba’nın çalışmasında araştırma grubundaki 1. ve 2. sinıftaki öğrencilerin psikolojik danışmanın etkisiyle altruistik değerleri önemli derecede artmış olmasına rağmen, 3. sinıftaki öğrencilerin altruistik değerleri önemli ölçüde artmamıştır. ${ }^{33}$ İyi niyetli olmayı, diğerlerine karşı duyarlı olmayı, fedakârlık etmeyi ve benmerkezci tutumdan uzak olmayı içeren kavram olarak tanımlanan altruistik değer, 1. sınıf öğrencilerinde üniversite gibi yeni bir ortama girdikleri için kişiler ile ilişki kurma ihtiyacı hissetmeleri, değer yargılarını ve kimliklerini yeni oluşturmaları vb. gibi nedenlerle altruistik değerleri yüksek çıkmakta iken; 4. sınıf öğrencilerinde, toplumun daha çok rekabet ortamına alıştırması sonucunda bireyciliğin ön plana çıkması, mezun olmak için ders geçme sorunları yaşamaları, mezuniyet sonrası iş bulma sıkıntısı ile birlikte ortaya çıkan gelecek kaygısı gibi daha birçok sorunla baş etmek zorunda kalmaları nedeniyle düşük çıktığı yorumu yapılabilir.

Diğer bir bulgu olan yaş ile altruistik değer arasında istatistiksel açıdan anlamlı bir farklılık saptanmıştır. Bu sonuç; yapılan bazı araştırma sonuçları tarafından desteklenmektedir. Chou, Hong Kong’taki Çinli ergenler üzerinde yaptığ çalışmada altruistik davranışta bulunmada yaşın önemli bir etkisi olduğunu; ${ }^{34}$ Mutafçılar öğretmenlerin altruistik değerlerinin incelendiği çalı̧̧masında, katılımcı öğretmenlerin yaşları ile altruistik değerleri arasında düşük düzeyde, pozitif ve anlamlı bir ilişki olduğunu bulmuştur. ${ }^{35}$ Ümmet'in üniversite öğrencilerine yönelik araştırmasında, 23 yaş ve üzerinde olan öğrencilerin 23 yaşından küçük olan öğrencilere göre daha fazla altruistik davranışta bulunduklarını ortaya koymaktadır. Başka bir deyişle öğrencilerin yaşları arttıkça altruistik davranışları da artmaktadır. ${ }^{36}$ Araştırmada ortaya çıkan farklılıkta ise; herhangi bir çıkar gözetmeksizin başkalarına yardım etme eğilimi olan altruistik değer, 18- 19 yaş arasında olan bireylerin altruistik değerleri, 23- 25 yaş arasındaki bireylere oranla daha yüksek olduğu görülmüştür. 18-19 yaş grubundaki bireylerin diğer yaş gruplarına oranla insanlara yardım etmekten daha çok mutluluk duydukları sonucu çıkarılabilir. Yaş ilerledikçe insanlar yardıma ihtiyacı olan birini gördüklerinde başına bir şey gelebileceği korkusuyla, yardım etmeyi mutluluk olarak

31 Figen Kasapoğlu, “İyilik Hali ile Özgecilik Arasındaki İlişkinin İncelenmesi”, Hikmet Yurdu, 7/13 (2014), s.280. 32 Kâşif Ak, "Üniversite Öğrencilerinin Özgecilik Düzeylerinin Yordayıcısı Olarak Yaşam Amaçları", Yüksek Lisans Tezi, Gaziosmanpaşa Üniversitesi, 2013, s.45.

33 Sırrı Akbaba, "Grupla Psikolojik Danışmanın Sosyal Psikolojik Bir Kavram Olan Özgecilik Üzerindeki Etkisi”, Doktora Tezi, Atatürk Üniversitesi, 1994, s.113.

34 Kee-Lee Chou, "Effect of Age, Gender and Participation in Volunteer Activities on the Altruistic Behavior of Chinese Adolescents", The Journal of Genetic Psychology, 159/2 (1998), s.199.

35 Mutafçılar, Işıl, "Özgecilik Kavramının Tarihsel Gelişimi ve Öğretmen Özgeciliği Üzerine Bir Araştırma”, Yüksek Lisans Tezi, Yeditepe Üniversitesi, 2008, s.168.

36 Durmuş Ümmet, "Üniversite Öğrencilerinde Özgecilik Davranışının Transaksiyonel Analiz Ego Durumlar ve Yaşam Doyumu Bağlamında İncelenmesi”, Doktora Tezi, Marmara Üniversitesi, 2012, s.138. 
görmedikleri sonucuna ulaşılabilir. ${ }^{37}$

Başka bir bulgu ise, organ bağışı konusunda sahip olunan "korku ve endişe" ile organ bağışlama tutumu arasında ters bir ilişki bulunmuştur. Öğrencilerinin, organ bağ1şına ilişkin korku ve endişeleri arttıkça; organ bağışlama tutumları da azalmaktadır.

Çalışmanın önemli bir sonucu da, araştırmaya katılan öğrencilerin benlik saygısı ile organ bağışı tutumları arasında orta seviyede ve pozitif yönde istatistiksel olarak anlamlı bir ilişki olduğu bulunmuştur. Bu sonuç, öğrencilerin benlik saygıları yükseldikçe altruistik değerlerinin de yükseldiği anlamına gelmektedir. Güneş ve Conak’in asistan hekimlerle yaptıkları çalışmada benlik saygısı ile organ bağışı tutumları arasında anlamlı bir ilişki bulunamamıştır. ${ }^{38}$ Falomir-Pichastor ve diğerleri, benlik saygısının organ bağışı ile ilgili tutum üzerinde olumlu bir etkisi olduğunu bulmuştur. Buna göre, bireyin altruistik değer yargıları, kendini yardımsever bir birey olarak algılaması ve bu rolün benlik kavramında taşıdığı önem, kişinin bağış kararını etkilemede ve niyetinde önemli bir yordayıcısıdır. ${ }^{39}$

Yapılan bir çalışmada bireyin organ bağışına karar vermesinin psikolojik riskleri ve faydaları açık bir şekilde tanımlanmış ve organ bağışının faydaları arasında bireyin benlik saygısında artma ve kişisel psikolojisinde iyileşme vb. gibi olumlu sonuçları yer verilmiştir. ${ }^{40}$ Thys vd.'nin alıcı, bağışçı ve ailede pediatrik canlı-verici böbrek ve karaciğer transplantasyonunun psikososyal etkisini ele alan çalışmada, organ bağ1şında bulunanların benlik saygısı ve toplum bilincinde artış görülmüşsür. ${ }^{41}$ Bağışçıların çoğunluğunda, organ bağışını ahlaki bir görev olarak gördükleri ve yardım etme arzusu güdüsüyle hareket ettiklerini, bağış sonucunda yüksek düzeyde memnun oldukları ve iyi işler yaptıkları duygusuyla benlik saygısında artış meydana gelmiştir. ${ }^{42}$

Benlik saygısı ile organ bağışına yönelik tutum arasında pozitif bir ilişki olduğundan kişilere benlik saygısı davranışı kazandırılması, bağışa yönelik uygulamaların arttırılmasında önemli bir konu olduğu görülmektedir. Yardımlaşma, sorumluluk alma, bağış yapma, işbirliğinde bulunma, hoşgörüye sahip olma gibi davranışların eğitim-kurumlarında desteklenmesi ve öğrencilerin bu davranışları geliştirecek etkinliklere katılımları gerekmektedir.

Alan çalışmasında yüz yüze anket yöntemi kullanıldığı için, organ bağışının yeterli oranda olmaması, çoğunlukla, olumlu bağış tutumlarının davranışa dönüştürüle-

\footnotetext{
37 Fikret Yaman, “Tüketici Davranışı Olarak Özgeciliğin İncelenmesi”, Tüketici ve Tüketim Araştırmaları Dergisi, 5/1 (2013), s.89.

38 Mehmet Emin Güneş ve Özge Conak, “Uzmanlık Öğrencisi Hekimlerin Benlik Saygısı Düzeylerinin Organ Bağışı Tutumlarına Etkisi”, Bakırköy Tip Dergisi, 13/4 (2017), s.201.

39 Juan M. Falomir-Pichastor, Jacques Berent ve Andrea Pereira, "Social Psychological Factors of Post-Mortem Organ Donation: A Theoretical Review of Determinants and Promotion Strategies", Health Psychology Review, 7/2 (2013), s.213.

40 Leonieke Kranenburg vd., “The Psychological Evaluation of Samaritan Kidney Donors: A Systematic Review”, Psychological Medicine, 38/2 (2008), s.179.

41 Kristof Thys vd., "Psychosocial İmpact of Pediatric Living-donor Kidney and Liver Transplantation on Recipients, Donors and The Family: A Systematic Review”, Transplant International, 28/3 (2014), s.270.

42 Evangelos Mazaris ve Vassilios Papalois, "Ethical Issues In Living Donor Transplantation", Experimental and Clinical Transplantation: Official Journal of The Middle East Society for Organ Transplantation, 4/2 (2006), s.6.
} 
memesinden kaynaklanmaktadır. Bu durum, bireylerin organların temin sürecinde iyi bilgilendirilmesi örneğin organ bağışının nereye ve nasıl yapılacağının bilinmesi önemini ön plana çıkarılmasını desteklemektedir. Organ bağışı konusunda bireyleri bilgilendirmek bağışa yönelik tutumları önemli derecede etkilemektedir. Ayrıca bu yolla kişilerin organ bağışı konusunda sahip oldukları korku ve endişeleri de azaltılabilir. Çalışmanın sonuçları, organ bağışı kampanyalarında, Sağlık Bakanlığı ve ilgili sivil kuruluşlar için bir veri kaynağı olarak kullanılabilir. Benzer çalışmalar toplumun farklı kesimleriyle ve daha geniş bir kitle ile yapılabilir.

\section{Kaynakça}

Acar, Muhammet Cevat ve Hıdır Apak. "Sosyal Hizmet Bölümü Öğrencilerinin Empatik Eğilimleri ile Özgecilik Düzeyleri Arasındaki İlişkinin İncelenmesi”. Toplum ve Sosyal Hizmet. 28/1 (2017): 93-112.

Ak, Kaşif. "Üniversite Öğrencilerinin Özgecilik Düzeylerinin Yordayıcısı Olarak Yaşam Amaçları”. Yüksek Lisans Tezi, Gaziosmanpaşa Üniversitesi, 2013.

Akbaba, Sırrı. "Grupla Psikolojik Danışmanın Sosyal Psikolojik Bir Kavram Olan Özgecilik Üzerindeki Etkisi”. Doktora Tezi, Atatürk Üniversitesi, 1994.

Akçöltekin, Alptürk. "Sınıf Öğretmenlerinin Organ Bağışı Tutumlarının Farklı Değişkenler Açısından İncelenmesi”. Karadeniz Uluslararası Bilimsel Dergi. 12/24 (2014): 52-63.

Akış, Mehtap, Ebru Katırcı, Hayriye Y. Uludağ, Bahriye Küçükkılıç, Turgut Gürbüz, Yasemin Türker, Hacer Kayacan, Kurtuluş Öngel ve Hüseyin Gül. "Süleyman Demirel Üniversitesi Personelinin Organ-Doku Bağışı ve Nakli Hakkındaki Bilgi ve Tutumları”. Süleyman Demirel Üniversitesi Tip Fakültesi Dergisi. 15/4 (2008): 28-33.

Altıok Öner, Hatice, Nurcan Ek ve Nermin Koruklu. “Üniversite Öğrencilerinin Benlik Saygı Düzeyi ile İlişkili Bazı Değişkenlerin İncelenmesi”. Adnan Menderes Üniversitesi Eğitim Fakültesi Eğitim Bilimleri Dergisi. 1/1 (2010): 99-120.

Arıcak, O. Tolga. “Üniversite Öğrencilerinde Benlik Saygısı”. Psikoloji Çalışmaları. 25 (2005): 19-30.

Başerer, Zeynep ve İbrahim Kısaç. “Özgeci Davranışın Psikolojik İyi Oluş ve Çeşitli Demografik Değişkenlere Göre İncelenmesi: Erzurum İli Örneği”. Akademik Sosyal Araştırmalar Dergisi. 5/56 (2017): 582- 594.

Bölükbaş, Nurgül, Ayşe Eyüpoğlu ve Pınar Kurt. “Organ Bağışı Hakkında Üniversite Öğrencilerinin Düşünceleri”. Ondokuz Mayıs Üniversitesi Tip Dergisi. 21/2 (2004): 73-77.

Chou, Kee-Lee. "Effect of Age, Gender and Participation in Volunteer Activities on the Altruistic Behavior of Chinese Adolescents". The Journal of Genetic Psychology. 159/2 (1998): 195-201.

Cillimoğlu, Ayhan Öznur, Sinan Yılmaz ve Mustafa Oğurlu. "Adnan Menderes Üniversitesi Hastanesi Personelinin Organ- Doku Bağışı ve Nakli Hakkındaki Bilgi ve Düşünceleri”. Türk Nefroloji Diyaliz ve Transplantasyon Dergisi. 25/3 (2016): 1-9. 
Çuhadaroğlu, Füsun. “Adölesanlarda Benlik Saygısı”. Yayımlanmamış Uzmanlık Tezi, Hacettepe Üniversitesi, 1986.

Demir Çelebi, Çiğgdem, Halil Eksi ve Mine Sayın. "Üniversite Öğrencilerinin Özgecilik ve Otantiklik Seviyeleri Arasındaki İlişkinin İncelenmesi”. Değerler Ĕ̆itimi Dergisi. 14/32 (2016): 79-102.

Demir Doğan, Melike, İbrahim Uzun, Nahsan Kaya, Hasan Ekinci ve Muhammed Altınkaynak. "Üniversite Öğrencilerinin Organ Bağışına Bakış Açısı ve Bilgi Düzeyleri”. Sağlık Bilimleri ve Meslekleri Dergisi. $3 / 2$ (2016): 99-105.

Durmuş, Beril, Serra Yurtkoru ve Murat Çinko. Sosyal Bilimlerde Spss'le Veri Analizi. İstanbul: Beta Yayınevi, 2013.

Durur, Fatih ve Yasemin Akbulut. “Türkiyede Organ Nakline Yönelik Politikaların Değerlendirilmesi”. Business and Management Studies: An International Journal. 5/3 (2017): 570-585.

Erbil, Nülüfer ve Özgül Bostan. "Ebe ve Hemşirelerde İş Doyumu, Benlik Saygısı ve Etkileyen Faktörler”. Atatürk Üniversitesi Hemşirelik Yüksekokulu Dergisi. 7/3 (2004): 56-66.

Erşan, E. Erdal, Orhan Doğan ve Selma Doğan. "Beden Eğitimi ve Antrenörlük Bölümü Öğrencilerinde Benlik Saygısı Düzeyi ve Bazı Sosyo-Demografik Özelliklerle İlişkisi”. Klinik Psikiyatri. 12/1 (2009): 35-42.

Falomir-Pichastor, Juan M., Jacques Berent ve Andrea Pereira. “Social Psychological Factors of Post-Mortem Organ Donation: A Theoretical Review of Determinants and Promotion Strategies". Health Psychology Review. 7/2 (2013): 202-247.

Güneş, Mehmet Emin ve Özge Conak. "Uzmanlık Öğrencisi Hekimlerin Benlik Saygısı Düzeylerinin Organ Bağışı Tutumlarına Etkisi”. Bakırköy Tip Dergisi. 13/4 (2017): 195-202.

Kalaycı, Şeref. SPSS Uygulamalı Çok Değişkenli İstatistik Teknikleri. Ankara: Asil Yayın Dağıtım, 2005.

Kara, Selami, Zeliha Salman ve Kurtuluş Öngel. "Süleyman Demirel Üniversitesi Tıp Fakültesi Sağlık Personelinin Organ Bağışına Bakışı”. Ankara Sağlık Hizmetleri Dergisi. 11/1 (2012): 33-39.

Karadağ, Gülendam, İlkay Güner, Döndü Çuhadar Özlem Uçan. "Gaziantep Üniversitesi Sağlık Yüksekokulu Hemşirelik Öğrencilerinin Benlik Saygıları”. Fırat Sağlık Hizmetleri Dergisi. 3/7 (2008): 29-42.

Karaırmak, Özlem ve Rahşan Siviş-Çetinkaya. "Benlik Saygısının ve Denetim Odağının Psikolojik Sağlamlık Üzerine Etkisi: Duyguların Aracı Rolü”. Türk Psikolojik Danışma ve Rehberlik Dergisi. 4/35 (2011): 30-43.

Kasapoğlu, Figen. “İyilik Hali ile Özgecilik Arasındaki İlişkinin İncelenmesi”. Hikmet Yurdu. 7/13 (2014): 271-288.

Kavurmac1, Mehtap, Neziha Karabulut ve Ayşegül Koç. "Üniversite Öğrencilerinin Organ Bağışı Hakkındaki Bilgi ve Görüşleri”. Hemşirelikte Eğitim ve Araştırma Dergisi. 11/2 (2014): 15-21. 
Koçak, Aytaç, Ekin Özgür Aktaş, Ender Şenol, Ahsen Kaya ve Erdar Bilgin. "Ege Üniversitesi Tıp Fakültesi Öğrencilerinin Organ Nakli ve Bağışı Hakkındaki Bilgi Düzeyi”. Ege Tip Dergisi. 49/3 (2010): 153-160.

Kranenburg, Leonieke, Willij Zuidema, Robert Erdman, Willem Weimar, Jan Passchier ve Jan Busschbach. "The Psychological Evaluation of Samaritan Kidney Donors: A Systematic Review”. Psychological Medicine. 38/2 (2008): 177-185.

Mazaris, Evangelos ve Vassilios Papalois. "Ethical Issues In Living Donor Transplantation". Experimental and Clinical Transplantation: Official Journal of The Middle East Society for Organ Transplantation. 4/2 (2006): 1-37.

McGinley, Meredith ve Gustavo Carlo. “Two Sides of The Same Coin? The Relations Between Prosocial and Physically Aggressive Behaviors". Journal of Youth and Adolescence. 36/3 (2007): 337.

Mutafçılar, Işıl. "Özgecilik Kavramının Tarihsel Gelişimi ve Öğretmen Özgeciliği Üzerine Bir Araştırma”. Yüksek Lisans Tezi, Yeditepe Üniversitesi, 2008.

Özdağ, Nurten. “Organ Nakli ve Bağışına Toplumun Bakışı”. Cumhuriyet Üniversitesi Hemşirelik Yüksekokulu Dergisi. 5/2 (2001): 46-55.

Özer, Nadiye, Serdar Sarıtaş ve Zeynep Karaman Özlü. "Hemşirelik Öğrencilerinin Organ Nakli ve Bağışı Konusundaki Bilgi ve Düşüncelerinin İncelenmesi”. Anadolu Hemşirelik ve Sağlık Bilimleri Dergisi. 13/2 (2010): 1-11.

Özkan, Sultan ve Emel Yılmaz. "Hasta Yakınlarının Organ Bağışı ile İlgili Bilgi ve Tutumları". Aile ve Toplum. 5/17 (2009): 18-29.

Özkan, İshak. “Benlik Saygısını Etkileyen Etkenler”. Düşünen Adam. 7/3 (1994): 4-9. Özpulat, Funda. "Üniversite Öğrencilerinin Kan ve Organ Bağışına İlişkin Düşünceleri”. Sağlık Bilimleri ve Meslekleri Dergisi. 4/2 (2017): 71-79.

Rosenberg, Morris. Society and The Adolescent Self-Image. New Jersey: Princeton University Press, 1965.

Rushton, J. Philippe, David W. Fulker, Michael C. Neale, David K. B. Nias ve Hans J. Eysenck. "Altruism and Aggression: The Heritability of Individual Differences". Journal of Personality and Social Psychology. 50/6 (1986): 1192-1198.

Sam, Neslihan, Rıza Sam ve K. Burcu Öngen. "Üniversite Öğrencilerinin Çevresel Tutumlarının Yeni Çevresel Paradigma ve Benlik Saygısı Ölçeği İle İncelenmesi”. Akademik Bakış Açısı. 21 (2010): 1-16.

Sezek, Fatih, Ercan Kaya, Zehra Akman, Bağdat Erbil, Büşra Aslan, Rüya Özgen ve Özge Keleş. "Üniversite Öğrencilerinin Öğrenim Gördükleri Alanlara Göre Organ Nakli ve Bağışı İle İlgili Görüşleri”. Ekev Akademi Dergisi. 19/62 (2015): 471-486.

Tanrıverdi, Derya, Esen Savaş, Nurcan Gönüllüoğlu, Ebru Kurdal ve Ganime Balık. "Lise Öğrencilerinin Yeme Tutumları, Yeme Davranışları ve Benlik Saygılarının İncelenmesi”. Gaziantep Tip Dergisi. 17/1 (2011): 33-39.

Taşgit, Muhammet Sıddık. "Üniversite Öğrencilerinin Benlik Saygısı ve Karar Verme Düzeylerinin İncelenmesi”. Yüksek Lisans Tezi, Karamanoğlu Mehmet Bey Üniversitesi, 2012. 
Thys, Kristof, Karl-Leo Schwering, Marion J. Siebelink, Fabienne Dobbels, Pascal Borry, Paul Schotsmans ve Isabelle Aujoulat. "Psychosocial İmpact of Pediatric Living-donor Kidney and Liver Transplantation on Recipients, Donors and The Family: A Systematic Review". Transplant International. 28/3 (2014): 270-280.

Tokay Arğan, Mehpare. "Organ Bağışını Artırmada Sosyal Pazarlama Yaklaşımı: Organ Bağışına Yönelik Bir Tutum Araştırması”. Doktora Tezi, Anadolu Üniversitesi, 2007.

Uzuntarla, Yasin. "Genç Yaş Grubunun Organ Bağışına Yönelik Düşünce ve Bilgi Düzeylerinin Verilen Eğitime Göre Karşılaştırılması”. Türk Nefroloji Diyaliz ve Transplantasyon Dergisi. 25/3 (2016): 296-301.

Ümmet, Durmuş. “Üniversite Öğrencilerinde Özgecilik Davranışının Transaksiyonel Analiz Ego Durumlar ve Yaşam Doyumu Bağlamında İncelenmesi”, Doktora Tezi, Marmara Üniversitesi, 2012.

Yaman, Fikret. "Tüketici Davranışı Olarak Özgeciliğin İncelenmesi”. Tüketici ve Tüketim Araştırmaları Dergisi. 5/1 (2013): 79-92.

Yaşin Tekizoğlu, Fatma. "Organ Bağışı: Bireylerin Kararlarını Etkileyen Psikolojik Faktörler”. Muhakeme Dergisi. 1/1 (2018): 21-34.

Yeter, Elif ve Savaş Demirtaş. “Organ Nakilleri ve Organ Bağışının Önemi”, Erişim 25 Ekim, 2018, http://kisi.deu.edu.tr/bulent.cavas/ders/bok3.pdf.

Yücetin, Levent, Nilgün Keçecioğlu ve Fettah Fevzi Ersoy. "Türkiye’de Organ Bağı̧ı1 ve Nakline Bir Bakış". Diyaliz Transplantasyon ve Yanık. 14/2 (2003): 115-118.

Yüksel, Havva ve Sadi Evren Seker. "Türkiyede Organ ve Doku Bağışının Bilgisayarlı Argüman Delfi Yöntemiyle Öngörülmesi”. Uluslararası Sağlı Yönetimi ve Stratejileri Araştırma Dergisi. 2/1 (2016): 12-24. 


\title{
Self-Respect and Organ Donation Attitude Relationship: A Research on University Students
}

HARUN KIRILMAZ / PELINSU BUKET GÜLER

\begin{abstract}
The purpose of this study is to examine the relationship between university students' self-esteem levels and organ donation attitudes. The research sample was composed of 250 students studying at Sakarya University Faculty of Business Administration. The "Organ Donation Attitude Scale", "Self Respect Scale" and personal information form belonging to students were used as data collection tools. According to research findings, information about organ donation was obtained mostly via visual media. University students' self-esteem is moderate. Positive and statistically significant relationships were found between self-esteem and organ donation attitude. Self-esteem affects organ donation positively. The level of selfesteem of university students is thought to increase with the level of organ donation attitude. In addition, there was a significant difference between altruistic value, which is the sub-dimension of organ donation attitude scale, and sex, age and class. Activities such as organ donation trainings, the explanation of the precepts, and the participation of young people in donation campaigns will be useful for raising awareness and awareness of the donations of the students and the community.
\end{abstract}

Keywords: Self-respect, Organ plantation, Organ donation. 